\title{
Erythroid Series Cells Decreased
}

National Cancer Institute

\section{Source}

National Cancer Institute. Erythroid Series Cells Decreased. NCI Thesaurus. Code C96203.

A morphologic finding indicating the presence of a decreased number of erythroid cells in the bone marrow. 